\title{
A Note on the Ancient Idea of a Danube with two Estuaries $^{1}$
}

\author{
Michal Habaj
}

(University of SS Cyril and Methodius, Trnava)

\begin{abstract}
Thanks to Theopompus and the story of Argonauts, the idea of a double Danube estuary spread throughout Greece in the $4^{\text {th }}$ century BC. According to this idea, the river flowed into the Adriatic as well as the Black Seas. This paper adds several notes to this topic based on a contextual analysis of both Theopompus' report and one passage of a text by Pseudo-Aristotle. Based on these two texts, the paper highlights several factors that may have played a role in creating the idea of a Danube bifurcation.
\end{abstract}

\section{Keywords}

Ancient geography; Danube; Theopompus; Pseudo-Aristotle

1 I would like to thank the anonymous referees for carefully reading my manuscript and for constructive comments. 
Sometime before the $4^{\text {th }}$ century $\mathrm{BC}$, a report spread among the Greeks that the Danube passes through the entire Balkans and connects the Black Sea with the Adriatic Sea. ${ }^{2}$ One of the first authors to discuss this scenario was Theopompus (c. 380-c. 315 BC). ${ }^{3}$ The idea must have taken root subsequently, because we encounter this erroneous assumption in the Periplus of Pseudo-Scylax from the middle of the $4^{\text {th }}$ century (c. 340 $\mathrm{BC}$ ), where we read that the Danube passes through Istria, and that it then turns towards Egypt. ${ }^{4}$ In his Historia Animalium, Aristotle claimed that fish swim from the Black Sea to Istria, and onwards to the Adriatic Sea through the second Danube estuary. ${ }^{5}$ In the first half of the $3^{\text {rd }}$ century BC, Apollonius of Rhodes claimed that the Argonauts had passed from the Black Sea to the Adriatic Sea. ${ }^{6}$ The double estuary was also mentioned by Eratosthenes (c. 276-c. 195 BC), ${ }^{7}$ Hipparchus (c. 190-c. 120 BC), ${ }^{8}$ and Pseudo-Scymnus (110-100 BC), ${ }^{9}$ as well as in the hard-to-date work of Pseudo-Aristotle known as De Mirabilibus Auscultationibus. ${ }^{10}$ Cornelius Nepos also speaks of a double estuary. ${ }^{11}$ Later, Pliny the Elder wrote of underground channels, through which the Danube was connected to the Adriatic Sea, ${ }^{12}$ and Pomponius Mela, at a time when the Romans were familiar with the entire middle stream of the Danube, appealed to old tradition and spoke of two Danube rivers flowing into the Adriatic and the Black Seas. ${ }^{13}$ Another sign that this idea survived is illustrated in the Tabula Peutingeriana, in which the Sava does not flow into the Danube, but into the Adriatic Sea (Podossinov 2015: p. 129). Notwithstanding Mela's archaic reports, it is clear that the Romans disproved the double estuary theory when they conquered the territory along the Danube. Based on the latest knowledge acquired by the Roman legions, Diodorus and Strabo disproved that the Danube has an estuary in the Adriatic Sea. ${ }^{14}$

2 The theory emerged before the $5^{\text {th }}$ century, see the Aeschylus fragment (Schol. ad Apoll. Rhod. 4.282291b) and especially Dan (2015: p. 136) for the minting of two-headed coins in Istria in the $5^{\text {th }}$ and $4^{\text {th }}$ centuries BC. Also, one passage from Herodotus (4.33: speaks of gifts of the Hyperboreans coming to the Adriatic coasts) suggests that he knew about the theory, but that he probably did not believe it, because he does not mention it anywhere and adheres only to reports speaking of one estuary into the Black Sea. The second possibility is that Herodotus knew nothing of this notion, and that his report about the Hyperboreans had another basis.

3 Strab. 7.5.9.

4 Ps.-Scylax $§ 20$. However, the tradition of a double estuary is much older, and it spread widely by association with the legend of Argonauts, see more below.

5 Arist. Hist. An. 598b.

6 Ap. Rhod. Argon. 4. 284-293.

7 Strab. 7.5.9.

8 Strab. 1.3.15

$9 \quad$ Ps.-Scymn. F7a. Marcotte.

10 Arist. [Mir. ausc.] $\S 105$.

11 Recorded by Pliny in N.H. 3. 18. 127.

12 Plin. N.H. 9. 20. 53. Probably the vestiges of Theopompus' thesis that the Aegean and Adriatic Seas are connected through channels.

13 Pomp. Mela. 2.63.

14 Diod. 4.56.7; Strab. 1.3.15. 
To date, it remains unclear how this false geographic model arose and what notions preceded it. In this article, I will focus first on how researchers have tackled these questions to date. Subsequently, I will introduce several of my own views to explain how the bifurcation concept was created.

\section{Research to date}

Several authors have addressed the concept of a bifurcated Danube. In this paper, I have selected those solutions and proposals that, in my opinion, have provided the most important insights into how the concept was created. ${ }^{15}$ For instance, it is likely that the article by K. G. Brandis ${ }^{16}$ is familiar to everyone who researches the ancient perception of the Danube. Brandis examined all ancient literature related to the Danube, and on this basis he inferred the extent of Greek and Roman knowledge of individual sections of the Danube. To explain the idea of a bifurcation, Brandis appealed to the ancient thesis of Strabo and Diodorus ${ }^{17}$ who explained that the concept of a bifurcation may have arisen because authors mixed up rivers. For example, the famous river Istros - the lower Danube, which flowed into the Black Sea - may have been confused with a smaller river of the same name that flowed through Istria and into the Adriatic Sea. Ultimately, according to Strabo and Diodorus, the name Istria was derived from this unknown river. This ancient explanation is based on ideas from the period. In around $340 \mathrm{BC}$, Pseudo-Scylax confirmed that the river Istros passed through Istria, ${ }^{18}$ and Strabo and Diodorus lived with this impression. Neither author knew that no major rivers flowed through Istria into the Adriatic Sea. ${ }^{19}$ Both believed that the river Istros flowed through Istria, and that the idea of a Danube (Istros) flowing across the Balkans arose from a mixing up of the names.

Thus, Strabo and Diodorus, and later Brandis, imagine that the bifurcation theory resulted from the existence of an unknown river Istros flowing through Istria. However, it may be that the opposite is the case and the concept of a river flowing into the Adriatic Sea may have been fabricated downstream of bifurcation ideas. Brandis recognized the complexity of this problem; in his conclusion, he noted that the origin of the double estuary theory may have been a poor understanding of trade connections between the Black and Adriatic Seas. ${ }^{20}$

Fritz Wehrli reasoned in another way. He touched upon the bifurcation in relation to how evolving geographic knowledge changed the return route of the Argonauts in literature. According to Wehrli, the Istros replaced the older transportation options of the

15 But there are also others: Condurachi (1969); Timpe (1986); Pavan (1989); Dan (2011).

16 Brandis (1901).

17 Brandis (1901: col. 2121); Strab. 1.3.15; Diod. 4.56.

18 Ps.-Scylax $\$ 20$.

19 Shipley (2011: p. 105).

20 Brandis (1901: col. 2122). 
Argonauts in the legend, such as the Okeanos and Tanais, because of new geographic knowledge. In his opinion, the idea of a western Danube estuary was bolstered by expanding knowledge of rivers in the north, as well as by the location of the smaller river Istros in Istria (Wehrli 1955: pp. 154-157). Although he was only marginally interested in the bifurcation, Wehrli correctly assumed that the idea arose from the intertwining of deeply rooted ideas and new knowledge.

Alexander Podossinov elaborated upon the suggestions of Wehrli's thesis. In the double estuary tradition, he recognizes the ancient Greek idea of a connection between the Adriatic and Black Seas (Podossinov 2015: p. 128). He assumes that, in the archaic period when the Greeks were not familiar with the north of the Adriatic, the Mediterranean beyond Italy, or the areas behind Bosporus, they considered these routes as estuaries into an ocean that surrounded the entire mainland. Podossinov added that the same tradition placed the Adriatic estuary near the Bosporus in the north and understood that the Balkans were only connected to the rest of Europe by a narrow isthmus (Marcotte 2000: pp. 370-371). Podossinov further assumed that when news about the Mediterranean spread in Greece, the Danube entered the scene to connect the nearby Black and the Adriatic Seas in Greek imagery. According to Podossinov, the proximity of the Danube's second estuary to the northwest coast is underscored because both areas are terminologically similar: Histria/Istros, or Venadi/Venedi in the Tabula Peutingeriana. This theory is compelling, especially since it reveals the assumptions that may have paved the way for the bifurcation theory. The ideas of an isthmus in the north Balkans, a small peninsula, and a waterway that connected the two, probably played an important role in the creation of the bifurcation construct.

In summary, previous research has introduced many factors that have shaped our understanding of how the double estuary tradition was created. Brandis mentioned that there was likely a poor understanding of trade connections between the Black and Adriatic Seas. Wehrli suggested the process that may have led to the confusion, and Podossinov described its background assumptions. In this regard, I see several additional points that partially explain the inception of this idea.

\section{A note on the idea of a Danube bifurcation}

To explain the inception of the bifurcation theory, I believe that a contextual analysis of two texts is essential:

Theopompus FGrHist 115 F129 = Strab. 7.5.9.

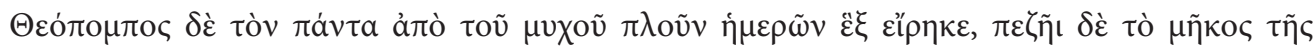

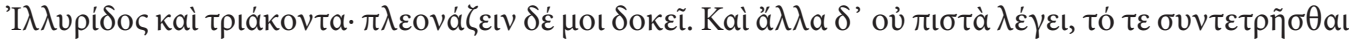

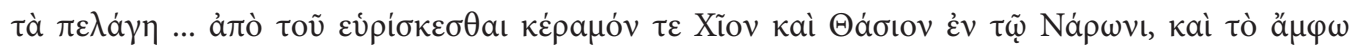

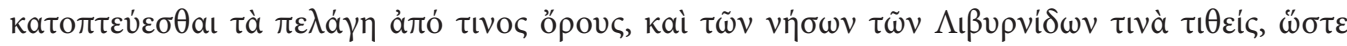

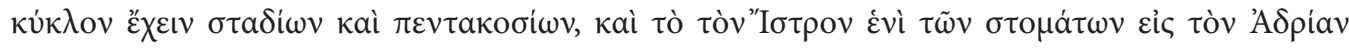

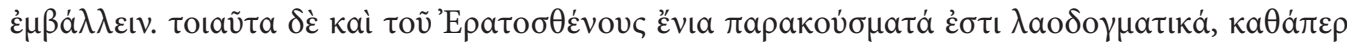

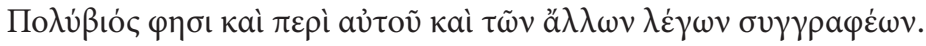


Pseudo-Aristoteles, De Mirabilibus Auscultationibus, 104.

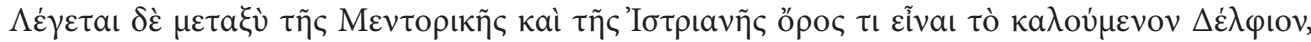

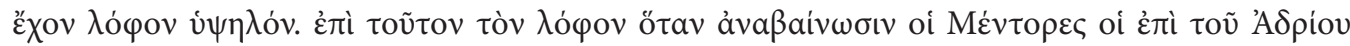

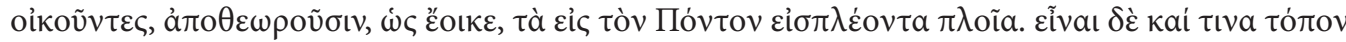

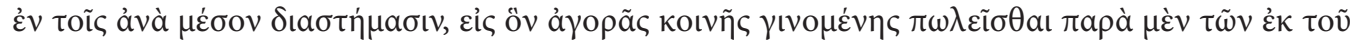

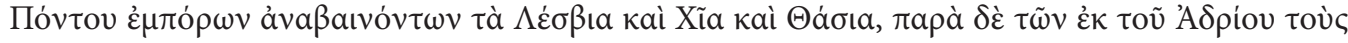

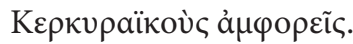

These texts originated in different periods. Theopompus lived in the $4^{\text {th }}$ century BC, but the report was only preserved in the work of Strabo. De Mirabilibus was authored after the $4^{\text {th }}$ century $\mathrm{BC}$, but both texts represent different variants of the same tradition. They are based on expanded reports of Greek trade on the Adriatic. Theopompus' report connects various traditions, but it primarily articulates the aforementioned idea of an isthmus in the Balkans. Theopompus does not speak of an isthmus between the Adriatic and Black Sea, but of one between the Adriatic and Aegean Seas, grounding his opinion on the Aegean pottery in the river Narenta. However, based on his reports of goods from the Aegean, it is clear that Theopompus replaced the Black Sea from the original tradition with the Aegean Sea. In his opinion, underground channels connect both seas. The same channels are mentioned at a later time by Pliny the Elder, ${ }^{21}$ and it may be that this tradition is connected with the freezing of the Danube, because Aelian mentions that this is what creates the underground channels. ${ }^{22}$

The second text - Pseudo-Aristotle's - illuminates Theopompus' report greatly. It mentions a market in the Balkans, where customers can buy goods from Lesbos, Chios, and Thasos on the Black Sea, as well as amphoras from Korkyra on the Adriatic. The same text speaks of the Danube trade route and offers an important detail: that ships sailing to the Black Sea can be seen from the mountain Delphinium. Reports of this kind may have contributed to a folk tradition about a mountain range from which both seas could be seen, ${ }^{23}$ especially since ideas of a narrow isthmus in northern Balkans were circulating. Assuming that the core purpose of Theopompus' report was to provide information about the Danube trade route, and not to focus on trade between the Aegean and Adriatic, it is likely that the Black Sea can be replaced by the Aegean, and that he is referring to a mountain from which both the Adriatic and Black Sea can be seen. Such an assumption is especially warranted in light of Pseudo-Aristotle's text, which discusses a similar matter, but in much greater detail. Pseudo-Aristotle does not speak of a mountain from which both seas can be seen, but of a mountain near the Adriatic from which ships sailing into the Pontus can be seen. In this regard, Theopompus - or his sources - have changed the original reports to make that fit more easily with his knowledge.

By way of comparison, Pseudo-Aristotle's text provides information about a trade route, whereas Theopompus' distorts these trade reports and confuses them with rooted geographical ideas. In various reports of goods flowing from East to West across the

21 Plin. N.H. 9.20.53.

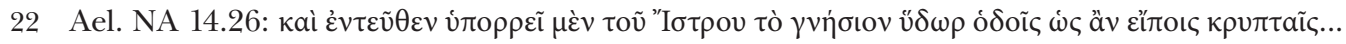

23 E. g. Liv. 40.21.2ff. 
Balkans, and vice-versa, the Danube and its tributaries represented a major part of the route. These reports were corrupted in an environment that was not in direct contact with this trade. That is, the tradition of an isthmus and a waterway between the Black and Adriatic Seas transformed the reports until it was believed that a branch of the Danube flowed into the Adriatic, and that the river connected the entire peninsula. Strabo attests that these reports were of a folk origin. ${ }^{24}$ Theopompus spread it throughout the Greek world in the $4^{\text {th }}$ century $\mathrm{BC},{ }^{25}$ just as he subsequently linked the idea with the legend of Argonauts. ${ }^{26}$ Pseudo-Aristotle, Diodorus, and Strabo asserted that the legend of Jason returning from Colchis via the Danube from the Black Sea to the Adriatic Sea contributed to the double estuary idea for generations of geographers. ${ }^{27}$

For a long time, the erroneous idea of a double estuary was possible because the Greeks had scant information about the Adriatic, and practically none about the northern parts. ${ }^{28}$ Until the $4^{\text {th }}$ century BC, the Greeks only knew of the northern areas thanks to sparsely placed trading stations (Castiglioni \& Lamboley 2015: pp. 154-55) and to contact with coastal tribes. In the $4^{\text {th }}$ century BC, this scenario changed slightly: the Greeks dared to travel further north, but mainly to the Italian coast and the Po estuary (Castiglioni \& Lamboley 2015: pp. 154-155). Few reports addressed the northern Balkans, and in the following centuries until the Roman expansion under Augustus, ${ }^{29}$ no one denied that the great river flowed into the Adriatic. The Greeks lacked clearer reports about these areas from the East, because their merchants were only familiar with the Danube up to the point where it meets the Sava. Because of the landscape, trade only took place along the inland valleys that led to the Danube (Dan 2015: p. 134). I believe that the idea of a western Danube arm was based on one of these tributaries, but it is impossible to prove which one. ${ }^{30}$ Ultimately, this may not have been any specific river, but the reports speaking of rivers connected to the Danube route. ${ }^{31}$ Such reports were simplified in folk consciousness based on rooted ideas, suggesting that a contextual shift had taken place as in the case of the reports of Theopompus and Pseudo-Aristotle.

24 Strab. 7.5.9.

25 Ps.-Scymn. 369-371, 380-381: In the second century he explicitly mentions that Theopompus was his source for the narrow seam dividing the Adriatic Sea from the Black Sea.

26 The scholion on Apollonius of Rhodes (4.282-291b) explicitly states that no one wrote of the journey of the Argonauts across the Danube until Timagetus $\left(4^{\text {th }}\right.$ century BC), from whom Apollonius took this version.

27 Arist. [Mir. ausc.] §105; Diod. 4.56.7; Strab. 1.3.15.

28 The Greeks did not establish colonies on the Dalmatian coast; their most northerly settlements were founded on today's island of Korčula, or in the area of today's city of Vis. The northernmost parts of eastern Adriatic remained unavailable to the Greeks due to frequent piracy, dangerous tribes, and often unfavorable ports. See Timpe (2007: p. 12).

29 Explicitly Diod. 4.56.7. New knowledge also contributed to reworking of the route of the Argonauts, which was no longer only on the Danube, but also on the Sava and across dry land. Plin. N.H. 3.18.128; Just. 32.3.3-14.

30 Recently, for example, an assumption emerged that this river might be Tagliamento, Shipley (2011: p. 105) or Natisone, Dan (2015: p. 138).

31 Pavan (1989: p. 12) showed, using fragments of Alcman and archeological findings of Greek helmets, that these reports may have originated in the $7^{\text {th }}$ or $6^{\text {th }}$ centuries BC. 


\section{Bibliography}

Brandis, K. G. (1901). Danuvius. In G. Wissowa, \& A. Pauly (Eds.), Realencyclopädie der classischen Altertumswissenschaft (Vol. IV,2; col. 2013-2132). Stuttgart: Metzler.

Castiglioni, M. P., \& Lamboley, J.-L. (2015). Les Grecs en Adriatique, bilan et perspectives. In Y. Marion, \& F. Tassaux (Eds.), AdriAtlas et l'histoire de l'espace adriatique de VI ${ }^{e}$ s. a. C. au VIII' s. p. C. Bordeaux: Ausonius.

Condurachi, E. (1969). Le Danube dans l'horizon géographique ancien. Starinar, N. S. 20, 29-34.

Dan, A. (2011). L'Istros chez Hérodote. Dacia, 55, 25-56.

Dan, A. (2015). Between the Euxine and Adriatic Seas: ancient representations of the Ister (Danube) and the Haemus (Balkan mountains) as images of modern South-Eastern Europe. In G. Tsetskhladze, A. Avram, \& J. Hargrave (Eds.), The Danubian Lands between the Black Aegean and Adriatic Seas (pp. 131-150). Oxford: Oxford University Press.

Marcotte, D. (2000). Pseudo-Scymnos. Circuit de la Terre. Paris: Les Belles Lettres.

Pavan, M. (1989). Miti e storia fra Danubio e Adriatico. Rivista di studi ungheresi, 4, 9-18.

Podossinov, A. (2015). Verbindung zwischen Schwarzem Meer und der Adriatik durch Ozean und/oder Donau im Weltbild der archaischen Griechen. In G. Tsetskhladze, A. Avram, \& J. Hargrave (Eds.), The Danubian Lands between the Black Aegean and Adriatic Seas (pp. 125-130). Oxford: Oxford University Press.

Shipley, G. (2011). Pseudo-Scylax's Periplous. Exeter: Phoenix.

Timpe, D. (1986). Donau. In J. Hoops, \& H. Beck (Eds.), Reallexikon der germanischen Altertumskunde (Vol. 6; pp. 17-26). Berlin: de Gruyter.

Timpe, D. (2007). Mitteleuropa in den Augen der Römer. Bonner Jahrbücher, 207, 5-32.

Wehrli, F. (1955). Die Rückfahrt der Argonauten. Museum Helveticum, 12, 154-157.

Doc. Michal Habaj, PhD. / michal.habaj33@gmail.com

University of Ss. Cyril and Methodius in Trnava

Nám. J. Herdu 2, 91701 Trnava, Slovakia 
